\title{
Chemical pollutants from an industrial estate in Pakistan: a threat to environmental sustainability
}

\author{
Qaisar Mahmood ${ }^{1} \cdot$ Shahida Shaheen ${ }^{1} \cdot$ Muhammad Bilal $^{1} \cdot$ Madiha Tariq $^{1} \cdot$ Bibi Saima $_{\text {Zeb }}{ }^{1} \cdot$ Zahid Ullah $^{2}$. \\ Arshad $\mathrm{Ali}^{3}$
}

Received: 10 October 2016 / Accepted: 6 March 2019 / Published online: 18 March 2019

(c) The Author(s) 2019

\begin{abstract}
Industrial sector is the backbone of the development of a country; however, its untreated effluents are damaging various ecological phenomena. Every day huge amounts of municipal, industrial and agricultural wastes are being released into the environment, causing serious ecological problems. Pakistan is currently experiencing profound demographic, economic changes and energy crisis that pose serious limitations on spending capital on water treatment. However, no serious effort has been put forth by any agency in Pakistan to characterize the exact nature and concentrations of contaminants found in wastewaters originating from various industrial zones. The current study aimed to characterize the industrial effluent quality of Hattar Industrial Estate, Hattar, Pakistan. The effluent samples were collected from five different drains, each having the combined effluent of many industries. All the samples were characterized for $\mathrm{pH}$, temperature, TS, TDS, TSS, EC, DO, BOD, COD, turbidity, nitrates $\left(\mathrm{NO}_{3}-\mathrm{N}\right)$, phosphates $\left(\mathrm{PO}_{4}\right)$, ammonia $\left(\mathrm{NH}_{4}-\mathrm{N}\right)$ and different heavy metals according to the standard methods. Majority of the water quality parameters exceeded the National Environmental Quality Standards in the country. These pollutants may have serious impacts on the soil profile, groundwater quality and freshwater ecosystems and thus need attention of policy makers to install a centralized wastewater treatment plant.
\end{abstract}

Keywords Industrial effluents $\cdot$ Pollutants $\cdot$ Heavy metals $\cdot$ Ecosystems $\cdot$ Water quality

\section{Introduction}

Water is a colorless, odorless and tasteless essential compound. We clean and wash with it. The agricultural sector cannot function without water and industries use it in various manufacturing processes. We living beings need water as it makes up more than $70 \%$ of our body. In short, life cannot exist without water. Sadly, water is being polluted at an alarming rate due to various factors like rapid industrialization. In Pakistan, wastewater being released from various

Qaisar Mahmood

mahmoodzju@gmail.com; drqaisar@cuiatd.edu.pk

1 Department of Environmental Sciences, COMSATS University Islamabad, Abbottabad Campus, Islamabad 22060, Pakistan

2 Department of Environmental Sciences, Allama Iqbal Open Uiversity, Islamabad 44000, Pakistan

3 Military College of Engineering (MCE), National University of Sciences and Technology (NUST), Risalpur Campus, Islamabad, KPK, Pakistan industrial sectors is usually released into the surrounding areas damaging human and animal life (Rehman et al. 2008). One of such industrial estates is Hattar Industrial Estate (HIE). It consists of around 117 operational units that are mainly composed of food and beverage, textile, crockery, paper printing, cement, publishing, chemical, rubber and leather products. This industrial estate is releasing a diverse range of pollutants into their nearby natural drains. These pollutants have very long-lasting effects on the sustainability of local ecosystems and pose a serious threat to human health. Industrial wastewaters contain many recalcitrant hazardous organic compounds like PCB, PAH, VOCs, etc. and inorganic compounds like heavy metals which can cause damage to delicate aquatic ecosystems. Some of these metals are potentially toxic or carcinogenic at sufficient concentrations and can cause serious human health hazards if they enter the food chain. Investigations have been made about the extent of the heavy metal pollution of surface water, ground water, soils, air and vegetation by mining and associated industrial activities, particularly thermal power plants and opencast coalmines (Benvenuti et al. 1997; Coulthard 
and Macklin 2003; Fang et al. 2003; Gluec et al. 2001; Khan et al. 2005). However, no serious effort has been put forth by any agency in Pakistan to characterize the exact nature and concentrations of contaminants found in wastewaters originating from HIE.

Wastewater treatment is necessary for allowing it to mix with other water bodies that are used for irrigation, drinking and other purposes. However, it is not possible to come up with a suitable water treatment plan without knowing about the nature of wastewater to be treated. In this study, the wastewater originating from HIE was characterized to determine the nature and concentrations of the contaminants. All the samples were characterized for $\mathrm{pH}$, temperature, TS, TDS, TSS, EC, DO, BOD, COD, turbidity, nitrates $\left(\mathrm{NO}_{3}-\mathrm{N}\right)$, phosphates $\left(\mathrm{PO}_{4}\right)$, ammonia $\left(\mathrm{NH}_{4}-\mathrm{N}\right)$ and different heavy metals (HMs) according to the standard methods. The results found helped to come up with useful recommendations related to the treatment of wastewater being released from HIE.

\section{Materials and methods}

\section{Study area}

HIE is situated near Kot Najibullah, a small town some $15 \mathrm{~km}$ from the city of Haripur in Hazara District. HIE was established in 1985-1986 and is spread over an area of 1443 acres. It contains more than a hundred industrial units with a majority of the units being export oriented. The industrial units here comprise of food and beverages with Qarshi Industries, Coronet Food (English Biscuits), Shezan International Limited, Kims Biscuits and Sweets and many more. There are food canning industries, PET bottle manufacturing units and various other packing units. Vegetable and ghee industries are also found here. Dewan Group of Companies the top industrialists of Pakistan have also set up a cement manufacturing plant, acrylic fiber plant and textile units. Chemical, plastic, rubber goods, leather products, crockery, carpets, paper printing and various other industries have also been established here. The Heavy Electrical Complex is also situated in Hattar; it produces power tools, power generators and electric transformers.

\section{Wastewater sampling of combined drains of HIE}

Five combined drains receiving the effluent of different industries were selected (Table 1). The wastewater samples were collected from all the drains during three different sampling periods, i.e., during March, June and November. During every sampling period, three samples were collected from each combined drain in clean plastic bottles. Temperature, electrical conductivity (EC), $\mathrm{pH}$, turbidity and total dissolved solids (TDS) were measured on-site. The wastewater bottles were brought to laboratory and kept at $4{ }^{\circ} \mathrm{C}$ for further analysis.

\section{Analytical procedures for wastewater quality parameters}

The samples were analyzed for various physicochemical parameters like $\mathrm{pH}$, electrical conductivity (EC), total dissolved solids (TDS), total solids (TS), total suspended solids (TSS), biochemical oxygen demand (BOD), chemical oxygen demand (COD), nitrates-nitrogen $\left(\mathrm{NO}_{3}-\mathrm{N}\right)$, ammonium-nitrogen $\left(\mathrm{NH}_{4}-\mathrm{N}\right)$, phosphates, dissolved oxygen (DO) and various heavy metals $(\mathrm{Cd}, \mathrm{Pb}, \mathrm{Cu}, \mathrm{Ni}, \mathrm{Cr}, \mathrm{Mn}$, $\mathrm{Fe}$ and $\mathrm{Hg}$ ). EC, $\mathrm{pH}$ and TDS were determined by using $\mathrm{pH}$ meter (Hanna, HI 991003 Sensor Check pH), while turbidity meter was determined by conductivity meter (Hanna, HI 9835 Microprocessor). The DO was determined by DO meter. BOD was estimated by 5-day BOD test (5210 B standard method) and COD by SM 5220 D method. Standard methods $1540 \mathrm{C}$ and $2540 \mathrm{D}$ were used to estimate TS and TSS of the wastewater samples of different combined drains. Standard method of 4500-P was used for phosphate determination, and $4500-\mathrm{NO}_{3}-\mathrm{N}$ was used for nitrate determination (APHA 2005).

All the reagents used in the wastewater quality parameter analysis were of analytical grade, and the instruments used for the analysis were of precise accuracy. The various heavy meals in the wastewater collected from all the five combined drains were detected by atomic absorption spectroscopy (AAS), as described by the APHA 2005. At least three readings were taken for each parameter each time, and then, mean value was calculated.
Table 1 Description of various sampling points

\begin{tabular}{ll}
\hline Combined drain & Receiving the effluents from industries \\
\hline Drain \#1 (D1) & Oil/Ghee mills, soap industry, match factory, beverage industry, Uni-Tech carpets \\
Drain \#2 (D2) & Beverage industry, oil and ghee industries, chemical industries \\
Drain \#3 (D3) & Steel mill, pharmaceutical industry, food industry, cable mills, carpet mills \\
Drain \#4 (D4) & Steel mill, carpet factory, synthronic industry, paper mills \\
Drain \#5 (D5) & Steel mills, chemical industries, carpet mills, paper mills, poultry protein mills \\
\hline
\end{tabular}

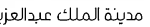
KACST مدلِية الملكَ 


\section{Results and discussion}

The $\mathrm{pH}$ of five different combined drains of HIE (drains 1, 2, 3, 4 and 5) was calculated at different time periods (Table 2). The $\mathrm{pH}$ of the effluents from the five drains was found to be between 4.6 and 10.9; i.e., it ranged from acidic to alkaline. Only a few drains had a neutral $\mathrm{pH}$ (7.0-7.8). Drain 1(D1) had slightly alkaline to strong alkaline $\mathrm{pH}$ (8.8-10.9). The $\mathrm{pH}$ of drain 2 (D2) was neutral to alkaline (7.5-10.04).

The temperature of the samples ranged from 10.7 to $47.13{ }^{\circ} \mathrm{C}$ during June 2012, November 2012 and March 2013 as shown in Table 2. D5 had the highest temperature during June 2012, and the lowest temperature was that of D3 in November 2012. During March 2013, the effluents form all the drains showed the highest value $\left(29.2-45.4{ }^{\circ} \mathrm{C}\right)$. Although the temperature of the samples from different drains of HIE was high, most samples met the NEQS $\left(40^{\circ} \mathrm{C}\right)$. Only five effluent samples were above the limit.

The EC of wastewater samples from drains (D1, D2, D3, D4 and D5) of HIE is presented in Table 3. EC values were found to be different during the different sampling times. D2 showed the highest EC as compared to the other samples. Its EC value was found to be $(2765 \mu \mathrm{S} / \mathrm{cm})$ during June. The lowest EC value (702) was observed for samples from D5 during March. Even the minimum EC $(702 \mu \mathrm{S} / \mathrm{cm})$ obtained during the study was greater than the permissible limits (300 $\mu \mathrm{S} / \mathrm{cm})$.

Turbidity of the HIE drains was also measured during June, November and March. It was observed that the turbidity of the samples was between 11.8 NTU and 32.3 NTU. The mean turbidity values of the selected drains are given in Table 2 along with standard deviations. The effluent samples analysis results showed that turbidity was higher during March to June as compared to values in November as shown in Table 3.
Table $2 \mathrm{pH}$ and temperature of combined drains of HIE

Table 3 EC and turbidity of combined drains of HIE

Table 4 TS and TDS of combined drains of HIE

\begin{tabular}{|c|c|c|c|c|c|c|}
\hline \multirow[t]{2}{*}{ SP } & \multicolumn{3}{|l|}{$\mathrm{pH}$} & \multicolumn{3}{|c|}{ Temperature $\left({ }^{\circ} \mathrm{C}\right)$} \\
\hline & March & June & November & November & March & June \\
\hline D1 & $10.9^{*} \pm 0.09^{\mathrm{A}}$ & $8.8 \pm 0.1$ & $10.7^{*} \pm 0.05$ & $28.4 \pm 0.2$ & $23 \pm 1$ & $29.2 \pm 0.2$ \\
\hline D2 & $7.5 \pm 0.3$ & $10.04 * \pm 0.12$ & $7.6 \pm 0.2$ & $26.2 \pm 0.2$ & $18.8 \pm 0.15$ & $43.3 \pm 0.35$ \\
\hline D3 & $6.9 \pm 0.058$ & $7 \pm 0.06$ & $4.6^{*} \pm 0.25$ & $29.5 \pm 0.41$ & $10.7 \pm 0.15$ & $40 \pm 2$ \\
\hline D4 & $8.3 \pm 0.25$ & $10.6^{*} \pm 0.2$ & $6.8 \pm 0.1$ & $24.6 \pm 0.3$ & $18.6 \pm 0.3$ & $41 \pm 1$ \\
\hline D5 & $6.4 \pm 0.1$ & $7.8 \pm 0.1$ & $7.6 \pm 0.2$ & $47.13 \pm 0.15$ & $24.2 \pm 0.26$ & $45.4 \pm 0.37$ \\
\hline \multicolumn{7}{|c|}{ NEQS 6-10 } \\
\hline
\end{tabular}

$S P$ sampling points, $D$ drain, $A$ (mean $\pm \mathrm{SD}$ ), *below or above NEQS; $n=45$

\begin{tabular}{|c|c|c|c|c|c|c|}
\hline \multirow[t]{2}{*}{ SP } & \multicolumn{3}{|l|}{$\mathrm{EC}(\mu \mathrm{S} / \mathrm{cm})$} & \multicolumn{3}{|c|}{ Turbidity (NTU) } \\
\hline & June & November & March & June & November & March \\
\hline D1 & $794.7 \pm 3.5^{\mathbf{A}}$ & $1205.7 \pm 3.1$ & $1663 \pm 1$ & $25.3 \pm 0.6$ & $18 \pm 1$ & $26.8 \pm 0.2$ \\
\hline D2 & $2765 \pm 1$ & $1965 \pm 2.5$ & $1845 \pm 1$ & $14.2 \pm 0.2$ & $14.7 \pm 0.2$ & $19.53 \pm 0.1$ \\
\hline D3 & $2451 \pm 1$ & $854.3 \pm 2.1$ & $1051 \pm 1$ & $32.3 \pm 0.6$ & $21.4 \pm 0.4$ & $26 \pm 1$ \\
\hline D4 & $1151.3 \pm 1.5$ & $1101.3 \pm 0.6$ & $977 \pm 1$ & $16.5 \pm 0.3$ & $11.8 \pm 0.2$ & $18.3 \pm 0.6$ \\
\hline D5 & $1051.7 \pm 2.1$ & $608.3 \pm 1.2$ & $702 \pm 2$ & $21.8 \pm 0.6$ & $16.3 \pm 0.6$ & $20.6 \pm 1.2$ \\
\hline
\end{tabular}

$S P$ sampling points, $D$ drain, $A$ (mean $\pm \mathrm{SD}), n=45$

\begin{tabular}{|c|c|c|c|c|c|c|}
\hline \multirow[t]{2}{*}{ SP } & \multicolumn{3}{|l|}{ TS (mg/L) } & \multicolumn{3}{|l|}{ TDS (mg/L) } \\
\hline & June & November & March & June & November & March \\
\hline D1 & $2001 \pm 1^{\mathbf{A}}$ & $1332.3 \pm 1.1$ & $811.6 \pm 0.5$ & $1021 \pm 1$ & $779 \pm 1$ & $392.3 \pm 1.5$ \\
\hline D2 & $1402 \pm 2.5$ & $1280 \pm 1$ & $1502 \pm 1$ & $967.3 \pm 1.5$ & $581 \pm 1$ & $722.3 \pm 1.5$ \\
\hline D3 & $2401 \pm 1.7$ & $1866.6 \pm 0.6$ & $1280.6 \pm 1.2$ & $498 \pm 1$ & $710.3 \pm 1.5$ & $580 \pm 2$ \\
\hline D4 & $966.6 \pm 1.5$ & $1051.3 \pm 1.5$ & $1266 \pm 2$ & $514.6 \pm 0.5$ & $442.6 \pm 2.5$ & $544.3 \pm 1.1$ \\
\hline D5 & $872 \pm 1.5$ & $1106 \pm 1$ & $968 \pm 1$ & $628.3 \pm 0.5$ & $614.3 \pm 0.5$ & $546.6 \pm 1.5$ \\
\hline
\end{tabular}

$S P$ sampling Points, $D$ Drain, $A$ (mean $\pm \mathrm{SD}), n=45$ 
The TS and TDS of the selected drains D1, D2, D3, D4 and D5 are presented in Table 4. During June, the maximum TSS level (2401 mg/L) was observed for effluent samples obtained from D3. Results showed that the minimum turbidity values were $811.6 \mathrm{mg} / \mathrm{L}$ (D1), $872 \mathrm{mg} / \mathrm{L}$ (D5) and $1051.3 \mathrm{mg} / \mathrm{L}$ during March, June and November, respectively. Similarly the TDS were analyzed for the five different drains of HIE and are tabulated in Table 4. The observed values when compared with the NEQS $(3500 \mathrm{mg} / \mathrm{L})$ showed that all the values were in the range of national standards. The minimum and maximum TDS values were observed as $392.3 \mathrm{mg} / \mathrm{L}$ (March) and $1021 \mathrm{mg} / \mathrm{L}$ (June) for D1. All the TDS values were within the permissible limits.

The mean TSS values of 5 HIE drains are given in Table 4. The results show that mean values of TDS obtained for samples from D3 were $1902 \mathrm{mg} / \mathrm{L}$ and $1160.6 \mathrm{mg} / \mathrm{L}$ which were the maximum during June and November, while effluent samples of D5 had minimum TDS mean values of $247 \mathrm{mg} / \mathrm{L}$ and $410 \mathrm{mg} / \mathrm{L}$ during June and March. The TDS level of all effluent samples obtained from five drains was above the maximum permissible limit of NEQS $(150 \mathrm{mg} / \mathrm{L})$.

The recorded DO concentrations of the different drains effluents of HIE are shown in Table 5. All the sampling drains (D1, D2, D3, D4 and D5) had low DO concentration during the different sampling times. The DO concentration $(1.8 \mathrm{mg} / \mathrm{L})$ of the D1 sampling drain remained similar, during the three different time periods, i.e., June, November and March. The minimum DO $(0.02 \mathrm{mg} / \mathrm{L})$ concentration was found for D4 during June. DO concentrations of the samples obtained from all the drains were below the NEQS permissible limits ( $>5 \mathrm{mg} / \mathrm{L})$.

\section{COD level of different drains of HIE}

The COD concentrations of effluent samples collected from five different drains of HIE during June, November and March are shown in Fig. 1. During March 2013, the average COD concentrations of D1, D2, D3, D4 and D5 were $464 \mathrm{mg} / \mathrm{L}, 385.3 \mathrm{mg} / \mathrm{l}, 555.3 \mathrm{mg} / \mathrm{L}, 497 \mathrm{mg} / \mathrm{L}$ and $377 \mathrm{mg} / \mathrm{L}$, respectively. The minimum COD concentration was found for D1 (267 mg/L), and the maximum COD concentration of D3 was $371 \mathrm{mg} / \mathrm{L}$ during November 2012. During June

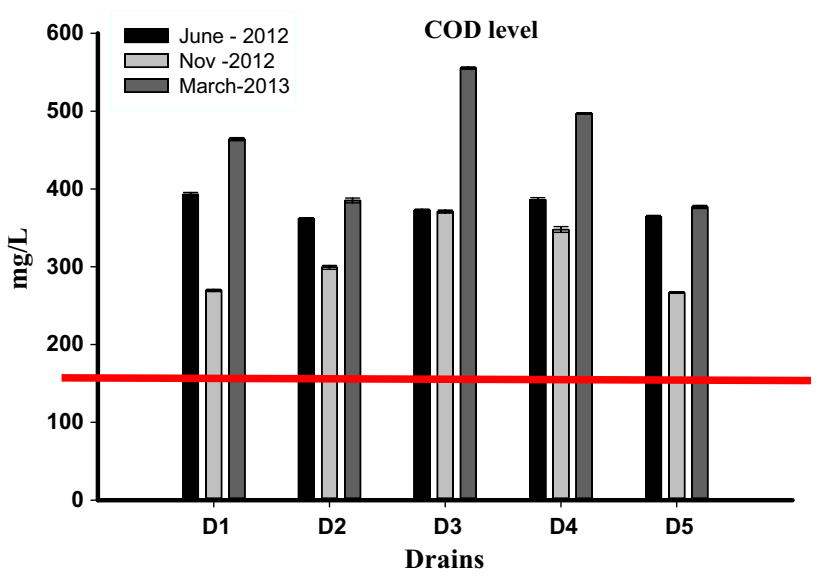

Fig. 1 COD level of different drains of HIE, Red line shows the NEQS value

2012, the COD concentrations for D1, D2, D3, D4 and D5 were $393 \mathrm{mg} / \mathrm{L}, 362 \mathrm{mg} / \mathrm{L}, 372.6 \mathrm{mg} / \mathrm{L}, 386.3 \mathrm{mg} / \mathrm{L}$ and $364 \mathrm{mg} / \mathrm{L}$, respectively, which were in medium pollution range. All the COD values obtained for the drains were above the permissible NEQS limit (Fig. 1).

\section{BOD level of different drains of HIE}

The BOD of samples obtained from five different drains (D1, D2, D3, D4 and D5) of HIE was calculated (Fig. 2). It was observed that samples from D4 had BOD higher than NEQS $80 \mathrm{mg} / \mathrm{L}$, i.e., $232 \mathrm{mg} / \mathrm{L}$ (June), $165.3 \mathrm{mg} / \mathrm{L}$ (November) and $238.3 \mathrm{mg} / \mathrm{L}$ (March). The BOD concentrations of D2 during November and March were $67 \mathrm{mg} / \mathrm{L}$ and $79.3 \mathrm{mg} / \mathrm{L}$, respectively. The values obtained were below the permissible limits.

\section{Nitrate $\left(\mathrm{NO}_{3}\right)$ level of different drains of HIE}

The nitrate concentrations were analyzed and are shown in Fig. 3. A variation in nitrate concentration of D1, D2, D3, D4 and D5 was observed during the different sampling times. The lowest concentration was found for D2, i.e., $6.2 \mathrm{mg} / \mathrm{L}$ of during June, while D5 had highest concentration
Table 5 TSS and DO of combined drains of HIE

\begin{tabular}{|c|c|c|c|c|c|c|}
\hline \multirow[t]{2}{*}{ SP } & \multicolumn{3}{|l|}{ TSS (mg/L) } & \multicolumn{3}{|l|}{$\mathrm{DO}(\mathrm{mg} / \mathrm{L})$} \\
\hline & June & November & March & June & November & March \\
\hline D1 & $981.6 \pm 1.5$ & $552 \pm 1$ & $421 \pm 1.5$ & $1.8 \pm 0.1$ & $1.8 \pm 0.1$ & $1.8 \pm 0.05$ \\
\hline D2 & $431.3 \pm 0.5$ & $701 \pm 0.5$ & $791 \pm 2$ & $3.2 \pm 0.01$ & $2.6 \pm 0.1$ & $1.5 \pm 0.3$ \\
\hline D3 & $1902 \pm 1$ & $1160.6 \pm 1.6$ & $710.3 \pm 1.5$ & $2.9 \pm 0.15$ & $2.6 \pm 0.2$ & $1.15 \pm 0.02$ \\
\hline D4 & $451.6 \pm 1.6$ & $610.3 \pm 1.5$ & $715 \pm 2$ & $0.02 \pm 0.01$ & $1.4 \pm 0.4$ & $0.12 \pm 0.03$ \\
\hline D5 & $247 \pm 2$ & $480.6 \pm 0.6$ & $410.6 \pm 0.6$ & $0.08 \pm 0.05$ & $0.07 \pm 0.02$ & $0.38 \pm 0.5$ \\
\hline
\end{tabular}

$S P$ sampling points, $D$ drain, $A($ mean $\pm \mathrm{SD})$ 


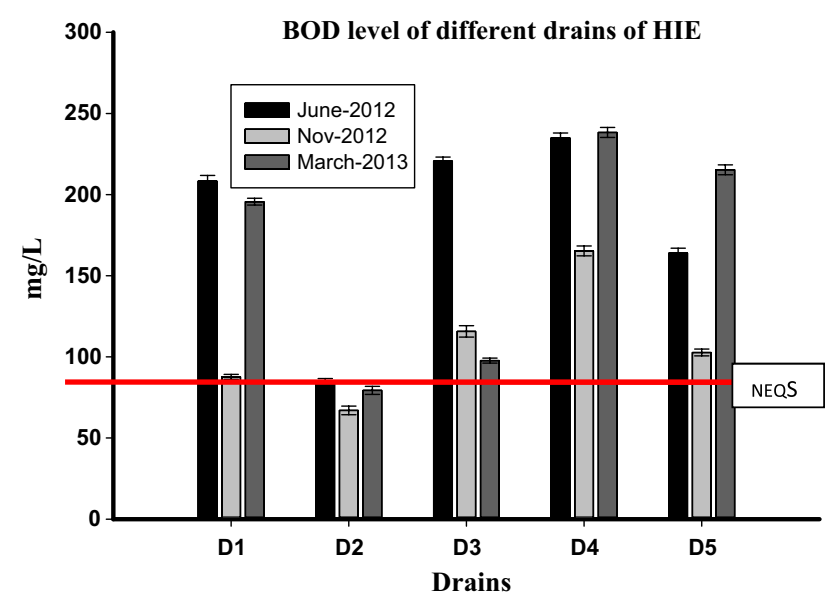

Fig. 2 BOD level of different drains of HIE. Red line shows the NEQS value

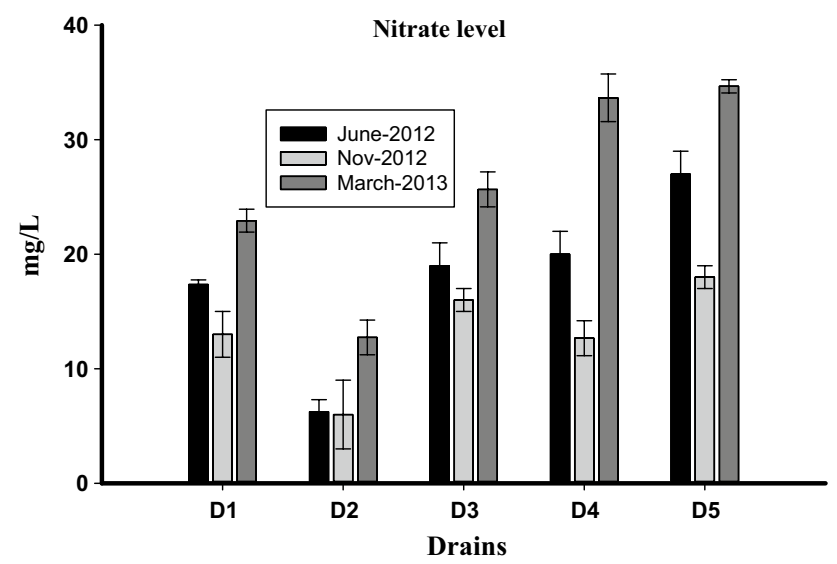

Fig. 3 Nitrate level of different drains of HIE

of $\mathrm{NO}_{3}$, i.e., $35 \mathrm{mg} / \mathrm{L}$ during November. A gradual increase was observed in nitrate concentration with the passage of time. The samples from all the five drains had higher nitrate concentrations during November and March as compared to June.

\section{Ammonium nitrogen $\left(\mathrm{NH}_{4}-\mathrm{N}\right)$ level of different drains of HIE}

The ammonium nitrogen levels were characterized during three different times, i.e., June, November and March (Fig. 4). All the effluent samples from the five drains showed ammonium nitrogen concentrations higher than the NEQS permissible limits $(40 \mathrm{mg} / \mathrm{L})$. D1 had the highest ammonium nitrogen concentration (151.6 mg/L) during March 2013, while the minimum concentration of $45 \mathrm{mg} / \mathrm{L}$ as found for D2 during November.

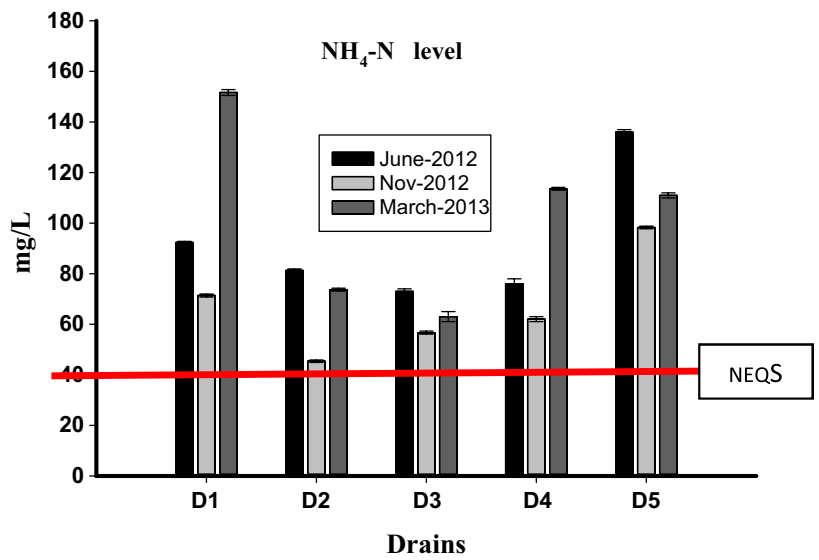

Fig. $4 \mathrm{NH}_{4}-\mathrm{N}$ level of different drains of HIE

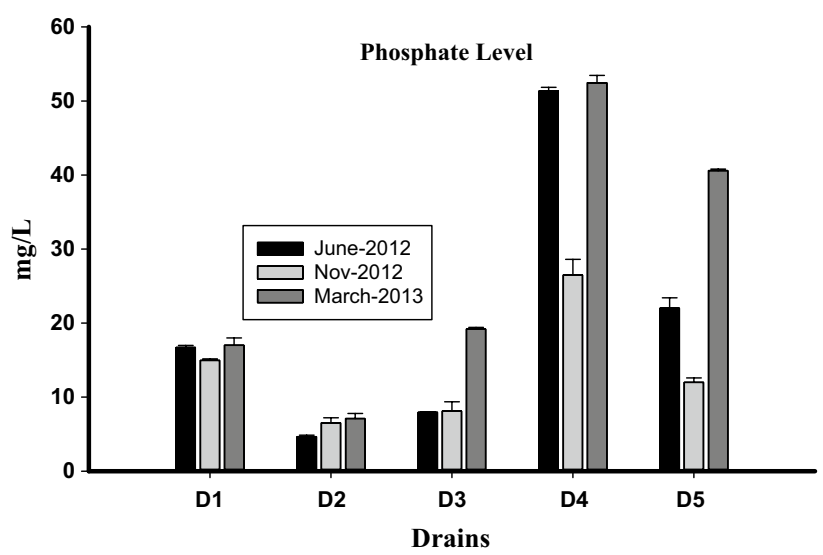

Fig. 5 Phosphate level of different drains of HIE

\section{Phosphate level of different drains of HIE}

The phosphate levels for D1, D2, D3, D4 and D5 of HIE were analyzed in June 2012 and found to be $16.7 \mathrm{mg} / \mathrm{L}$, $4.65 \mathrm{mg} / \mathrm{L} 7.95 \mathrm{mg} / \mathrm{L}, 51.4 \mathrm{mg} / \mathrm{L}$ and $22 \mathrm{mg} / \mathrm{L}$, respectively (Fig. 5). During June and March, the phosphate levels of the effluent samples obtained from D4 were $51.4 \mathrm{mg} / \mathrm{L}$ and $52.5 \mathrm{mg} / \mathrm{L}$, respectively. The phosphates levels for D4 were greater than all other effluent samples.

\section{Heavy metals (Cd, Pb, Cu, Ni, Cr, Zn, Fe and $\mathrm{Hg}$ )}

Heavy metals like $\mathrm{Cd}, \mathrm{Pb}, \mathrm{Cu}, \mathrm{Ni}, \mathrm{Zn}, \mathrm{Cr}, \mathrm{Mn}, \mathrm{Fe}$ and $\mathrm{Hg}$ were measured for five different drains of HIE for June (Table 6). D3 contained the lowest concentration of the $\mathrm{Cd}$, while D2 had the highest concentration of $\mathrm{Cd}$. The cadmium concentrations found for the five drains were within the permissible limits of NEQS $100 \mu \mathrm{g} / \mathrm{L}$. The $\mathrm{Pb}$ concentrations of the samples obtained from D2 $(612 \mu \mathrm{g} / \mathrm{L})$ and D3 $(1.5 \mathrm{mg} / \mathrm{L})$ were above the NEQS permissible limits of $500 \mu \mathrm{g} / \mathrm{L}$. Heavy 
metals like $\mathrm{Cu}, \mathrm{Zn}, \mathrm{Mn}, \mathrm{Cr}$ and $\mathrm{Ni}$ were within the permissible limits, but still it would be better to reduce their concentrations by treatment. Hg was found to be above the NEQS $(10 \mu \mathrm{g} / \mathrm{L})$ in all the effluent samples five drains during June.

Table 7 shows the results obtained when heavy metals were analyzed from the samples obtained from the drains during November. The heavy metals were found to be within permissible limits for all the drains with a few exceptions, i.e., $\mathrm{Cu}$ levels obtained for $\mathrm{D} 4$ and $\mathrm{Pb}$ for $\mathrm{D} 1$ were higher than the permissible limits. $\mathrm{Hg}$ showed a high concentration, i.e., 420 to $1800 \mu \mathrm{g} / \mathrm{L}$. Tables 6,7 and 8 show that the concentration of the some metals increased with the increasing time. Table 8 shows that D5 had high levels of heavy metals during March as compared to the rest of other four drains.

The characterization results show that the combined industrial effluent consists of wastewater being generated
Table 6 Heavy metal concentration in different drains of HIE during June-2012

Table 7 Heavy metal concentration in different drains of HIE during November

Table 8 Heavy metal concentration in different drains of HIE during March

\begin{tabular}{|c|c|c|c|c|c|}
\hline \multirow[t]{2}{*}{ Heavy metals } & \multicolumn{5}{|l|}{ June } \\
\hline & D1 & D2 & D3 & D4 & D5 \\
\hline $\mathrm{Cd}$ & $40 \pm 0.01$ & $70 \pm 0.01$ & $2 \pm 0.001$ & $33 \pm 0.01$ & $40 \pm .01$ \\
\hline $\mathrm{Pb}$ & $371 \pm 0.04$ & $612 \pm 0.05$ & $1.5^{*} \pm 0.02$ & $569 \pm 0.01$ & $342 \pm 0.001$ \\
\hline $\mathrm{Ni}$ & $117 \pm 0.01$ & $66 \pm 0.015$ & $117 \pm 0.002$ & $88 \pm 0.001$ & $433 \pm 0.07$ \\
\hline $\mathrm{Cu}$ & $120 \pm 0.01$ & $380 \pm 0.01$ & $390 \pm 0.01$ & $426 \pm 0.015$ & $460 \pm 0.01$ \\
\hline $\mathrm{Zn}$ & $46 \pm 0.02$ & $60 \pm 0.01$ & $213 \pm 0.002$ & $121 \pm 0.12$ & $123 \pm 0.002$ \\
\hline $\mathrm{Cr}$ & $346 \pm 0.04$ & $30 \pm 0.02$ & $214 \pm .10$ & $318 \pm 0.2$ & $367 \pm 0.01$ \\
\hline $\mathrm{Mn}$ & $13 \pm 0.01$ & $20 \pm 0.01$ & $10 \pm 0.03$ & $50 \pm 0.01$ & $98 \pm 0.001$ \\
\hline $\mathrm{Fe}$ & $66 \pm 0.01$ & $13 \pm 0.01$ & $34 \pm 0.01$ & $48 \pm 0.01$ & $83 \pm 0.01$ \\
\hline $\mathrm{Hg}$ & $450 \pm 0.23$ & $182 \pm 0.18$ & $172 \pm 0.02$ & $149 \pm 0.01$ & $191 \pm 0.01$ \\
\hline
\end{tabular}

All the heavy metal units are in $\mu \mathrm{g} / \mathrm{L}$; only * mg/L

\begin{tabular}{lccccc}
\hline Heavy metals & November & \multicolumn{3}{l}{} \\
\cline { 2 - 5 } & $\mathrm{D} 1$ & $\mathrm{D} 2$ & $\mathrm{D} 3$ & $\mathrm{D} 4$ & $\mathrm{D} 5$ \\
\hline $\mathrm{Cd}$ & $40 \pm .01$ & $24 \pm .002$ & $9 \pm .002$ & $43 \pm 0.02$ & $32 \pm .01$ \\
$\mathrm{~Pb}$ & $386 \pm 0.06$ & $609 \pm 0.06$ & $1.51^{*} \pm 0.01$ & $648 \pm 0.01$ & $1.49^{*} \pm 0.015$ \\
$\mathrm{Ni}$ & $271 \pm 0.1$ & $90 \pm 0.01$ & $117 \pm 0.002$ & $279 \pm 0.02$ & $2.02^{*} \pm 0.03$ \\
$\mathrm{Cu}$ & $360 \pm 0.02$ & $410 \pm 0.01$ & $1.34 \pm 0.03$ & $3.64^{*} \pm 0.04$ & $751 \pm 0.05$ \\
$\mathrm{Zn}$ & $56 \pm 0.01$ & $32 \pm 0.002$ & $275 \pm 0.01$ & $60 \pm 0.02$ & $540 \pm 0.002$ \\
$\mathrm{Cr}$ & $48 \pm 0.02$ & $0 \pm 0.00$ & $313 \pm 0.01$ & $666 \pm 0.06$ & $543 \pm 0.04$ \\
$\mathrm{Mn}$ & $20 \pm 0.01$ & $30 \pm 0.01$ & $53 \pm 0.01$ & $57 \pm 0.001$ & $104 \pm 0.002$ \\
$\mathrm{Fe}$ & $73 \pm 0.01$ & $20 \pm 0.01$ & $32 \pm 0.001$ & $453 \pm 0.02$ & $1.05^{*} \pm 0.03$ \\
$\mathrm{Hg}$ & $496 \pm 0.02$ & $420 \pm 0.01$ & $886 \pm 0.01$ & $2.06^{*} \pm 0.05$ & $1.80^{*} \pm 0.1$ \\
\hline
\end{tabular}

All the heavy metal units are in $\mu \mathrm{g} / \mathrm{L}$; only *mg/L

\begin{tabular}{lrccrc}
\hline Heavy metals & \multicolumn{1}{l}{ March } & \multicolumn{3}{c}{} \\
\cline { 2 - 5 } & \multicolumn{1}{c}{$\mathrm{D} 1$} & $\mathrm{D} 2$ & $\mathrm{D} 3$ & $\mathrm{D} 4$ & \multicolumn{1}{c}{$\mathrm{D} 5$} \\
\hline $\mathrm{Cd}$ & $73 \pm 0.01$ & $27 \pm 0.002$ & $76 \pm 0.011$ & $47 \pm 0.001$ & $222 \pm 0.11$ \\
$\mathrm{~Pb}$ & $466 \pm 0.18$ & $1200 \pm 0.1$ & $1.63^{*} \pm 0.06$ & $685 \pm 0.006$ & $2.433^{*} \pm 0.3$ \\
$\mathrm{Ni}$ & $1.36^{*} \pm 0.15$ & $403 \pm 0.2$ & $213 \pm 0.002$ & $279 \pm 0.02$ & $2.17^{*} \pm 0.01$ \\
$\mathrm{Cu}$ & $400 \pm 0.01$ & $423 \pm 0.005$ & $1.44 \pm .08$ & $3.8 \pm 0.04$ & $5.97 \pm 0.02$ \\
$\mathrm{Zn}$ & $80 \pm 0.01$ & $36 \pm 0.02$ & $288 \pm 0.003$ & $76 \pm 0.01$ & $1.11^{*} \pm 0.02$ \\
$\mathrm{Cr}$ & $510 \pm 0.03$ & $13 \pm 0.006$ & $460 \pm 0.02$ & $386 \pm 0.06$ & $367 \pm 0.01$ \\
$\mathrm{Mn}$ & $23 \pm 0.01$ & $20 \pm 0.01$ & $50 \pm 0.04$ & $255 \pm 0.01$ & $317 \pm 0.001$ \\
$\mathrm{Fe}$ & $73 \pm 0.01$ & $43 \pm 0.01$ & $157 \pm 0.01$ & $473 \pm 0.02$ & $1.02^{*} \pm 0.17$ \\
$\mathrm{Hg}$ & $526 \pm 0.05$ & $456 \pm 0.07$ & $1.22^{*} \pm 0.01$ & $2.36^{*} \pm 0.3$ & $2.022^{*} \pm 0.01$ \\
\hline
\end{tabular}

All the heavy metal units are in $\mu \mathrm{g} / \mathrm{L}$; only *mg/L 
from different industries, i.e., iron and steel industry, mines and quarries, food industry, complex organic chemical industry. The results pertaining to various physicochemical characteristics of combined effluents are shown in different figures and tables. The $\mathrm{pH}$ of different effluent samples lies between 4.6 and 10.9. It was observed most of the samples had $\mathrm{pH}$ values within the permissible limits; however, the $\mathrm{pH}$ of five effluent samples exceeded the NEQS.

The $\mathrm{pH}$ affects the chemical and biological processes in wastewater treatment (Alturkmani 2008). The acidic industrial effluents are responsible for altering the $\mathrm{pH}$ of receiving water bodies, thereby destabilizing alkalinity, metal solubility and hardness, i.e., the fundamental properties of water (Jüttner et al. 2000; Aboulhassan et al. 2006; Sianbola et al. 2011). Wang et al. (2002) also documented the fact that aquatic organisms' metabolic activities are also dependent on the $\mathrm{pH}$ values. The wastewater characteristics may also affect the microbial communities and their abundance (Shu et al. 2015; Ouyang et al. 2019). The biochemical reactions of aquatic organisms are temperature dependent (Mandal 2014; Hariharan et al. 2010). An increase in temperature of water body will promote chemical reactions in the water and affect solubility of gases. Gases are less soluble at higher temperature. This will affect the aquatic life and also impart bad taste and odor to the water. If DO levels drop below the 4-5 ppm limit, this will have serious detrimental effects toward survival of the aquatic species (WastewaterSystems. net/December 5, 2011). Turbidity is also of concern as it can alter the esthetic value of water by giving it a muddy or cloudy appearance. Turbidity can also hinder light penetration, disrupting aquatic life (Mandal et al. 2014).

Total dissolved solids if present in high amounts can reduce the light penetration into water and affect photosynthesis. This in turn can decrease the DO level of a given water body resulting in decreased purification of water by microorganisms (Nosheen et al. 2000). High amount of suspended solids can result in sludge build up if they settle at the bottom of the river bed. When decomposition occurs in the sludge layer, it will lead to oxygen deprivation and foul odor generation.

Effluent standards are usually imposed based on the needs of the receiving streams, on its locations and in particular on whether the streams have extended use and serve toward other purposes. Streams which serve as a source of potable and drinking water usually have stricter discharge standards as compared to the streams that flow directly to the sea.

There are a few quality limits which are often monitored as part of the wastewater discharge control standards, and the most important are COD, BOD, dissolved oxygen, suspended solids, nutrient levels, $\mathrm{pH}$ and bacteria. The COD and BOD are important water quality parameters in wastewater analysis. COD and BOD indirectly relate to the amount of organic and inorganic compounds present in the water sample. Effluents having high levels of COD and BOD can deplete the oxygen level of the receiving water bodies, creating anaerobic condition that is hostile to the aquatic organisms (Sial et al. 2006; Prashanth et al. 2006; Lima Neto et al. 2007). In Pakistan, the environmental standards are not being followed. Solid and liquid waste from industries is being dumped into nearby open sites, sewers, streams and creeks, resulting in high levels of the heavy metals in the ground water (Gulfraz 2000). Keeping in view the discriminatory effects of the industrial wastewater on the drinking water, soil and plants, some standards are set by the Government of Pakistan (Table 9).

Although heavy metals like iron, molybdenum, manganese, zinc, copper, magnesium, copper, selenium and nickel have a major role in the growth and development of plants, they are toxic beyond certain level (Metcalf, Eddy, Inc. 2003). During the last few decades, heavy metal pollution has increased drastically due to rapid industrialization.

Table 9 National environmental quality standards for industrial effluents

\begin{tabular}{lll}
\hline S. no. & Parameter & Standards \\
\hline 1. & Temperature & $40{ }^{\circ} \mathrm{C}$ \\
2. & pH value (acidity/basicity) & $6-10 \mathrm{pH}$ \\
3. & 5-day biochemical oxygen demand (BOD) at & $80 \mathrm{mg} / \mathrm{L}$ \\
& $\quad 20^{\circ} \mathrm{C}$ & \\
4. & Chemical oxygen demand (COD) & $150 \mathrm{mg} / \mathrm{L}$ \\
5. & Total suspended solids & $150 \mathrm{mg} / \mathrm{L}$ \\
6. & Total dissolved solids & $3500 \mathrm{mg} / \mathrm{L}$ \\
7. & Grease and oil & $10 \mathrm{mg} / \mathrm{L}$ \\
8. & Chloride (as Cl) & $1000 \mathrm{mg} / \mathrm{L}$. \\
9. & Mercury & $0.01 \mathrm{mg} / \mathrm{L}$ \\
10. & Fluoride (as F) & $20 \mathrm{mg} / \mathrm{L}$ \\
11. & Cyanide (as CN) & $2 \mathrm{mg} / \mathrm{L}$ \\
12. & Anionic detergents & $20 \mathrm{mg} / \mathrm{L}$ \\
13. & Sulfate & $600 \mathrm{mg} / \mathrm{L}$ \\
14. & Sulfide (S) & $1.0 \mathrm{mg} / \mathrm{L}$ \\
15. & Ammonia & $40 \mathrm{mg} / \mathrm{L}$ \\
16. & Pesticides, herbicides, fungicides and insecti- & $0.15 \mathrm{mg} / \mathrm{L}$ \\
& cides & \\
17. & Cadmium & $0.1 \mathrm{mg} / \mathrm{L}$ \\
18. & Chromium (trivalent and hexavalent) & $1.0 \mathrm{mg} / \mathrm{L}$ \\
19. & Copper & $1.0 \mathrm{mg} / \mathrm{L}$ \\
20. & Lead & $0.5 \mathrm{mg} / \mathrm{L}$ \\
21. & Selenium & $0.5 \mathrm{mg} / \mathrm{L}$ \\
22. & Nickel & $1.0 \mathrm{mg} / \mathrm{L}$ \\
23. & Silver & $1.0 \mathrm{mg} / \mathrm{L}$ \\
24. & Zinc & $5.0 \mathrm{mg} / \mathrm{L}$ \\
25. & Arsenic & $1.0 \mathrm{mg} / \mathrm{L}$ \\
26. & Iron & $2.0 \mathrm{mg} / \mathrm{L}$ \\
27. & Manganese \\
28. & Boron & $1.5 \mathrm{mg} / \mathrm{L}$ \\
\hline & & \\
\hline
\end{tabular}


Industrial chemicals are considered as the major contributors of heavy metals (Løbersli and Steinnes 1988). Heavy metals are toxic to humans, animals as well as plants. Due to the technical and economic constraints, it is challenging to clean up heavy metals from the soil and ground water (Rauser 1990: Chaudhry et al. 1998). One of the major environmental issues is the solubility of the.

Wastewater from individual industries like food industry, vegetable ghee industry and chemical manufacturing industry has been characterized (Aslam et al. 2004; Sial et al. 2006; Manzoor et al. 2004, 2006; Baloach et al. 2010; Amin et al. 2010) The present study only focused on the characterization of combined industrial effluents with the broad objective of evolving baseline data on the present status of distribution of toxic metals as well as physicochemical parameters of the wastewater which could help in designing a proper treatment plant for wastewater treatment.

Industrialization comes with an environmental cost if the effluents are released without treatment The current study characterized the industrial effluent discharge quality of HIE, Haripur. Effluent discharge samples were taken from five different drains, each drain receiving the combined effluent of many industries. All the samples were characterized for $\mathrm{pH}$, temperature, TS, TDS, TSS, EC, DO, BOD, COD, turbidity, nitrates, phosphates, ammonia and different heavy metals. Most of the samples exceeded NEQS. Therefore, there is a need for continuous monitoring and proper management of industrial effluents before discharging them into the surrounding. This helps to safeguard aquatic and human life.

Hence, it is concluded that the discharge of industrial effluents of HIE is resulting in high levels of contaminants in the environment. These pollutants are toxic to different organisms. The effluents may also have considerable negative effects on the water quality of the receiving water bodies, making them unfit for human use. It is, therefore, recommended that the careless disposal of industrial wastes without pretreatment should be discouraged. Integrated physicochemical and biological treatments may be suitable options to treat such industrial effluents before discharge into the environment (Firdous et al. 2018; Gulzar et al. 2018; Li et al. 2018). Imposition of strict check on industrial effluents by the regulating agency as well as continuous monitoring and surveillance is imperative in order to ensure the protection of water resources from further degradation.

\section{Conclusions}

1. Industrial effluents should be continuously monitored and properly managed before discharge in order to reduce potential damage aquatic and human life. It is evident that the discharge of HIE effluents invariably results in high concentrations of pollutants into sur- rounding soils and water bodies. Till date, no treatment facility has been installed by either the public or the private sector. The farmers are the ignorant of the gravity of situation regarding the health effects of pollutants, and they are using wastewater for the irrigation of crops grown in the area. Personally, it was observed that crops like wheat, maize, peas, onions, garlic, brassinoids, colocasia, potatoes, spinach, fodder crops and many fruit trees are being irrigated using these effluents. This may result in the bioaccumulation of hazardous pollutants in these food crops and thus pose health risk to the human lives. As the areas surrounding HIE are the commercial producers of various food crops, it is highly recommended that the health risk assessment of these contaminated food crops should be carried out to save the human life consuming these food items.

2. The most suitable treatment methods for such wastewaters are biological treatment technologies, especially anaerobic wastewater treatment along posttreatment wetland processes. The effective management of any wastewater flow requires reasonably accurate knowledge of its characteristics. This is particularly true for wastewater flows from rural residential dwellings, commercial establishments and other facilities where individual water-using activities create an intermittent flow of wastewater that can vary widely in volume and degree of pollution. Detailed characterization data regarding these combined flows are necessary not only to facilitate the effective design of wastewater treatment and disposal systems, but also to enable the development and application of water conservation and waste load reduction strategies.

Acknowledgements The authors acknowledge the Higher Education Commission of Pakistan for the financial support (Project No. NRPU 2122) to carry out this study.

\section{Compliance with ethical standards}

Conflict of interest The authors declare that they have not any conflict of interest.

Open Access This article is distributed under the terms of the Creative Commons Attribution 4.0 International License (http://creativeco mmons.org/licenses/by/4.0/), which permits unrestricted use, distribution, and reproduction in any medium, provided you give appropriate credit to the original author(s) and the source, provide a link to the Creative Commons license, and indicate if changes were made. 


\section{References}

Aboulhassan MA, Souabi S, Yaacoubi A, Baudu M (2006) Removal of surfactant from industrial wastewaters by coagulation flocculation process. Int J Environ Sci Tech 4:327-332

Alturkmani AA (2008) Dairy industry effluents treatment anaerobic treatment of whey in stirred batch reactor. PhD thesis. Sanitary Engineering and Water Protection Department. Technical University of Civil Engineering of Bucharest (UTCB)

Amin A, Ahmad T, Ehsanullah M, Irfanullah KM, Khan M (2010) Evaluation of industrial and city effluent quality using physicochemical and biological parameters. Electron J Environ Agric Food Chem 9:931-939

APHA (2005) Standard methods for the examination of water and wastewater, 21st edn. American Public Health Association, Washington, DC

Aslam M, Baig M, Hassan I, Qazi I, Malik M, Saeed H (2004) Textile wastewater characterization and reduction of its COD \& BOD by oxidation. Electron J Environ Agric Food Chem 3:804-811

Baloach M, Ali A, Durrani G, Rahim A (2010) Impact of industrial effluents of Gadoon Amazi Industries over quality of ground water. Asian J Water Environ Pollut 7:65-71

Benvenuti M, Mascaro I, Corsini F, Lattazi P, Parrini P, Tanilli G (1997) Mine water dumps and heavy metal pollution in abandoned mining district of Boccheggiano (Southern Tuscany, Italy). Environ Geol 30(3/4):238-243

Chaudhry TM, Hayes WJ, Khan AG, Khoo CH (1998) Phytoremediation-focusing on accumulator plants that remediate metal-contaminated soils. Australas J Ecotoxicol 4:37-51

Coulthard TJ, Macklin MG (2003) Modeling longterm contamination in river systems from historical metal mining. Geology 31(5):451-454

Metcalf, Eddy, Inc. (2003) Wastewater engineering treatment and reuse, 4th edn. McGrawHill, New York

Fang WX, Huang ZY, Wu PW (2003) Contamination of the environmental ecosystems by trace elements from mining activities of Badao bone coal mine in China. Environ Geol 44:373-378

Firdous S, Jin W, Shahid N, Bhatti ZA, Iqbal A, Abbasi A, Mahmood Q, Ali A (2018) The performance of microbial fuel cells treating vegetable oil industrial wastewater. Environ Technol Innov $10: 143-151$

Gluec N, Gunal B, Erler A (2001) Assessment of soil and water contamination around an ash-disposal site: a case study from the Seyentomer coal-fired power plant in Western Turkey. Environ Geol 40(3):331-344

Gulfraz M (2000) Contamination of selected metal ions in rivers and lakes water due to industries and their effect on aquatic life. Ph.D. Thesis, Quaid-i-Azam University, Islamabad

Gulzar F, Mahmood Q, Bhatti ZA, Zeb BS, Shaheen S, Hayat T, Shahid $\mathrm{N}$, Tahseen ZT (2018) Industrial wastewater treatment in internal circulation bioreactor followed by wetlands containing emergent plants and algae. World J Microbiol Biotechnol 34:119-125

Hariharan S (2010) A novel integrated instrumentation technique for air pollution monitoring. In: Gulfraz M (ed) 2010 International conference on environmental engineering and applications, IEEE. Contamination of selected metal ions in rivers and lakes water due to industries and their effect on aquatic life. Ph.D. Thesis, Quaidi-Azam University, Islamabad, pp 142-146

http://www.wwfpak.org/pdf/water-report.pdf. 2 Dec 2015

http://www.4enveng.com/userimages/INDUSTRIAL\%20WASTEWAT ER.pdf. 3 Dec 2015

http://www.meraharipur.com/daily/?tag=hattar-industrial-estate. 6 Dec 2015

http://ietd.inflibnet.ac.in/bitstream/10603/1616/10/10_chapter2.pdf. Accessed 5 Dec 2015
http://www.scribd.com/doc/37929846/4/Chemical-wastewater-chara cteristics. 5th Dec 2015

http://www.wastewatersystem.net/2011/10/effluent-standards-qualitydischarge.html. 6 Dec 2015

Jüttner K, Galla U, Schmieder H (2000) Electrochemical approaches to environmental problems in the process industry. Electrochimica Acta 45(15-16):2575-2594

Khan R, Israili SH, Ahmad H, Mohan A (2005) Heavy metal pollution assesment in surface water bodies and its suitability for irrigation around the Neyveli lignite mines and associated industrial complex, Tamil Nadu, India. Mine Water Environ 24:155-161

Li X, Chen X, Ma L, Wang H, Fan J (2018) Industrial wastewater advanced treatment via catalytic ozonation with an Fe-based catalyst. Chemosphere 195:336-343

Lima Neto I, Zhu DZ, Rajaratnam N, Yu T, Spafford M, McEachern $P$ (2007) Dissolved oxygen downstream of an effluent outfall in an ice-covered river: natural and artificial aeration. J Environ Eng 133:1051-1060

Løbersli EM, Steinnes E (1988) Metal uptake in plants from a birch forest area near a copper smelter in Norway. Water Air Soil Pollut 37(1-2):25

Mandal HK (2014) Influence of wastewater pH on Turbidity. Int J Environ Res Dev 4:105-114

Manzoor S (2006) Studies on chemical profiling of wastewater from Hattar Industrial Estate (NWFP), Pakistan. PhD Thesis, Department of Chemistry Quaid-e-Azam University Islamabad, p. 217

Manzoor S, Shah M, Shaheen N, Tariq S, Khaliq A, Jaffar M (2004) Distribution of heavy toxic metals in industrial effluents and relevant soils from selected oil and ghee industries in Hattar. J Chem Soc Pak 26:429-435

Nosheen S, Nawaz H, Khalil-ur-Rehma (2000) Physicochemical characterization of effluents of local textile industries of FaisalabadPakistan. Int J Agric Biol 2(3):232-233

Ouyang E, Liu Y, Ouyang J, Wang X (2019) Effects of different wastewater characteristics and treatment techniques on the bacterial community structure in three pharmaceutical wastewater treatment systems. Environ Technol 40:329-341

Prashanth S, Kumar P, Mehrotra I (2006) Anaerobic degradability: effect of particulate COD. J Environ Eng 132:488-496

Rauser WE (1990) Phytochelatins. Ann Rev Biochem 59(1):61-86

Rehman W, Zeb A, Noor N, Nawaz M (2008) Heavy metal pollution assessment in various industries of Pakistan. Environ Geol 55:353-358

Shu D, He Y, Yue $\mathrm{H}$ et al (2015) Microbial structures and community functions of anaerobic sludge in six full-scale wastewater treatment plants as revealed by 454 high-throughput pyrosequencing. Bioresour Technol 186:163-172

Sial RA, Chaudhary MF, Abbas ST, Latif MI, Khan AG (2006) Quality of effluents from Hattar Industrial Estate. J Zhejiang Univ Sci B 7(12):974-980

Siyanbola TO, Ajanaku KO, James OO, Olugbuyiro JAO, Adekoya JO (2011) Physico-chemical characteristics of industrial effluents in Lagos state, Nigeria. Glob J Pure Appl Sci Technol 1:49-54

Wang W, Yue X, Liu HJ, Pan Z, Tang DG, Wang Y et al (2002) Study on pollution characteristics of aerosol during sand dust storm weather in Beijing. Acta Sci Circumstantiae 22:494-498 [in Chinese with abstract in English]

Publisher's Note Springer Nature remains neutral with regard to jurisdictional claims in published maps and institutional affiliations. 